\title{
Journal med militær presisjon
}

\author{
Ett bilde sier mer enn tusen ord - i Tidsskriftet nr. 15-16/1936 redegjør revmatologen Magne Mortensson- \\ Egnund for et dansk tegnsystem til enkel fremstilling av pasientens tilstand (Tidsskr Nor Lægeforen 1936; 56: \\ 908-9). For å beskrive mobiliteten tar man utgangspunkt i «den militære grunnstilling». Begrepet er kanskje \\ ikke like mye brukt av legene i dag?
}

\section{Revmatologisk tegnsystem.}

\section{Av Magne Mortensson-Egnund, Hønefoss.}

Journalskrivning av revmatiske artropatier - særlig polyartriter er $\mathrm{i}$ almindelighet en langvarig og omstendelig historie, og det er vanskelig i en nogenlunde kortfattet form å gi et oversiktlig billede av patientens tilstand. En grafisk metode, i likhet med den tuberkuloselægene anvender, vilde derfor bety en stor lettelse.

Avdøde dosent, dr. med. Jansen ved det fysikalsk-terapeutiske institutt ved Bispeberg hospital, København, har utarbeidet et praktisk og lettvint tegnsystem, som man finner offentliggjort i Acta Rheumatologica nr. 10, september 1931.

Systemet består av i alt 9 tegn, som gir uttrykk for de forskjellige kliniske forhold og kan inntegnes på et vanlig nevrologisk skjema. Tegnene er slik konstruert at de kan føies inn i hverandre og kombineres $i$ alle mulige forhold.
Mobiliteten angis i grader ved siden av det angjeldende ledd. Man går ut fra den militære grunnstilling med strakte armer og hendene rett langs lårene, føttene i rett vinkel til leggen, men med fotsålene samlet. Ut fra denne stilling som betegnes med 0, angis enhver ekskursjon i grader i de forskjellige retninger.

Kan et håndledd eksempel dorsalmoveres $20^{\circ}$ er dette: dors. $0-20$, en helt normal bevegelighet betegnes med $0-\infty$, en total ankylose $i$ utgangsstilling er $0-0$, en vinkel på $60^{\circ}$ har man $60-60$.

Dette enkle og praktiske system anvendes i Danmark konsekvent i Giktsanatoriet ved Skelsør og i overlæge Sechers avdeling på Bispeberg hospital, men synes forøvrig å være mindre kjent. Tegnsystemet gjengives herved samt en del eksempler fra Acta Rheumatologica.

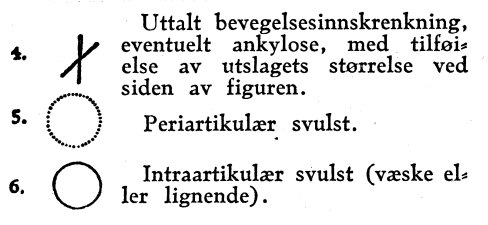

1. Ømhet kun ved ekstreme be= F vegelser.

2. - Ømhet så vel ved palpasjon

3. $Y$ Hemning, lett bevegelsesinn= skrenkning
tergrenser.

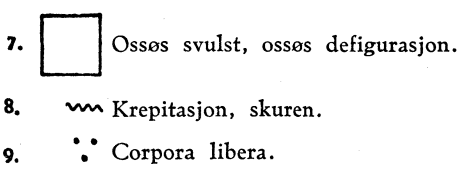

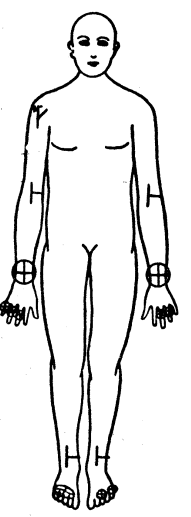

A.

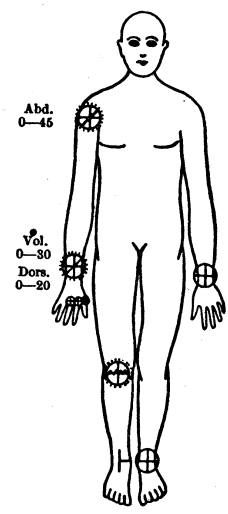

B.

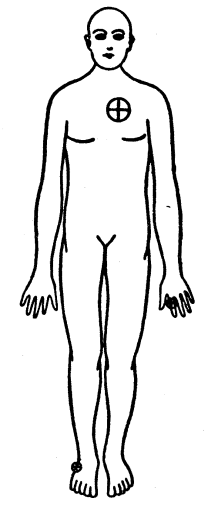

C.

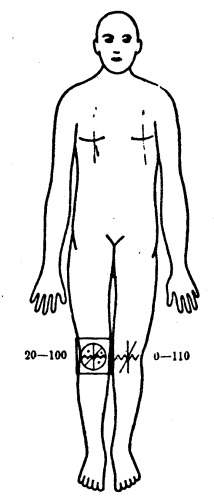

D.

Fig. A. Typisk primær kronisk progressiv polyartrit. Symmetrisk utbredelse, perifer begynnelse.

Fig. B. Fremskreden sekundær kronisk polyartrit. Assymmetrisk utbredelse, mindre og større ledd samtidig og likelig affisert.

Fig. C. Karakteristisk tilfelle av gonorreisk polyartrit med mere tilfeldige og spredte lokalisasjoner.

Fig. D. Typisk billede av osteoarthritis deformans genuum. Ossøs deformasjon, krepitasjon, corp. libra og innskrenkede bevegelser i $\mathbf{h}$ kneledd, samt lignende begynnende forandring $i$ det venstre. 